\title{
Ensino de Humanidades: O Percurso Geográfico e Histórico da Reforma Protestante
}

\author{
Enseñanza de Humanidades: El Recorrido Geográfico e Histórico de la \\ Reforma Protestante
}

Teaching Humanities: The Geographical and Historical Route of the

Protestant Reformation

\author{
Elsbeth Léia Spode Becker ${ }^{1}$ \\ Natália Lampert Batista ${ }^{2}$ \\ Tascieli Feltrin ${ }^{3}$
}

\begin{abstract}
Resumo
No ensino de humanidades, o constante contato com a Filosofia, a Arte, a Literatura, a História e a Geografia, o uso da imagem aliada ao texto renova a prática da indução e da reflexão do conhecimento. Assim, o principal objetivo foi organizar o infográfico, 'Caminhos da Reforma', para apresentar o contexto geográfico e histórico da Reforma, na atual Alemanha, trazendo textos históricos e imagens atuais das Igrejas e das cidades importantes, a partir de Wittenberg, a Igreja do Castelo onde foram fixadas as 95 teses. A metodologia está embasada no estado da arte, na perspectiva da pesquisa qualitativa que descreve a Reforma Protestante para o ensino de humanidades e no uso da cartografia para espacializar o contexto de vida do seu principal articulador, Martinho Lutero. O percurso do reformador foi delimitado no mapa a partir de informações bibliográficas, e as fotografias e os textos completaram o infográfico denominado 'Caminhos da Reforma'. O infográfico destina-se a estudantes do Ensino Médio, como um recurso multimodal que alia texto, mapa e imagens, e serve de motivação para o ensino em ambientes formais e não-formais.
\end{abstract}

Palavras-Chave: Ensino, Humanidades, Infografia, Multimodalidade.

\section{Resumen}

En la enseñanza de humanidades, el constante contacto con la Filosofía, el Arte, la Literatura, la Historia y la Geografía, el uso de la imagen aliada al texto renueva la práctica de la inducción y de la reflexión del conocimiento. Así, el infográfico 'Caminos de la Reforma' presenta el contexto geográfico e histórico de la Reforma, en la actual Alemania, trayendo textos históricos e imágenes actuales de las Iglesias y de las ciudades importantes, a partir de Wittenberg, la Iglesia del Castillo donde se fijaron las 95 tesis. La metodología está fundamentada en el estado del arte, en la perspectiva de la investigación cualitativa que describe la Reforma

\footnotetext{
${ }^{1}$ Graduação em Geografia (Bacharelado), Graduação em Geografia (Licenciatura Plena), Mestrado em Engenharia Agrícola e Doutorado em Agronomia na Universidade Federal de Santa Maria (UFSM). Atualmente, Professora adjunta no Centro de Ciências Humanas do Centro Universitário Franciscano e professora da rede pública estadual atuando no Ensino Médio em Santa Maria, RS. E-mail: elsbth.geo@gmail.com.

${ }^{2}$ Graduação em Geografia (Licenciatura) no Centro Universitário Franciscano e Mestrado em Geografia pelo Programa de Pós-graduação em Geografia (PPGGEO) na Universidade Federal de Santa Maria (UFSM). Atualmente, é doutoranda em Geografia no PPGGEO/UFSM e professora na rede municipal de Santa Maria, RS. E-mail: natilbatista3@gmail.com.

${ }^{3}$ Graduação em Letras licenciatura plena em Língua Portuguesa, Língua Espanhola e respectivas Literaturas na Faculdade Metodista de Santa Maria (FAMES), Especialista em Gestão Escolar e Mestra em Educação pelo Programa de Pós-graduação em Educação (PPGE) na Universidade Federal de Santa Maria (UFSM). Atualmente, professora na rede municipal de Santa Maria, RS. E-mail: tascifeltrin@gmail.com.
} 
Protestante para la enseñanza de humanidades y en el uso de la cartografía para espacializar el contexto de vida de su principal articulador, Martín Lutero. El recorrido del reformador fue delimitado en el mapa a partir de informaciones bibliográficas y las fotografías y los textos completaron el infográfico denominado 'Caminos de la Reforma'. El infográfico se destina a estudiantes de Enseñanza Media, como un recurso multimodal que combina texto, mapa e imágenes, y sirve de motivación para la enseñanza en ambientes formales y no formales.

Palabras claves: Enseñanza, Humanidades, Infografía, Multimodalidad.

\begin{abstract}
In the teaching of the humanities, the constant contact with Philosophy, Art, Literature, History and Geography, the use of the image allied to the text renews the practice of induction and reflection of knowledge. Thus, the main objective was to organize the infographic 'Reformation Paths' to present the historical and geographical context of the Reformation in present-day Germany, bringing historical texts and current images of Churches and important cities, from Wittenberg, Castle Church where were fixed the 95 theses. The methodology is based on the state of the art in the perspective of the qualitative research that describes the Protestant Reformation for the teaching of humanities and the use of cartography to spatialize the context of life of its main articulator, Martin Luther. The path of the reformer was delimited in the map from bibliographical information and the photographs and the texts completed the infographic called 'Paths of the Reformation'. The infographic is intended for high school students as a multimodal resource that combines text, map and images, and serves as a motivation for teaching in formal and non-formal environments.
\end{abstract}

Key words: Teaching, Humanities, Infographics, Multimodality.

\title{
1. Introdução
}

O momento em que Martinho Lutero ${ }^{4}$ rompeu com a Igreja Católica e iniciou a Reforma está completando 500 anos em 2017. O fato marcou a história da humanidade, especialmente na Europa e ficou conhecido como o grande cisma religioso. No entanto, a dimensão do fato foi muito maior no contexto laico do que no religioso, porque, sobretudo, provocou profundas transformações na sociedade da época. A jornalista Miriam Leitão (2017, p. 1) escreveu que "apesar de ter nascido de uma discussão teológica e doutrinária, a Reforma é, sobretudo, uma efeméride laica porque representou valores universais que marcaram o fim da Idade Média e prenunciaram o Iluminismo".

$\mathrm{O}$ ato de Lutero ocorreu em 31 de outubro de 1517. Martinho Lutero (1483-1546) era monge agostiniano ${ }^{5}$ e doutor em Teologia na Universidade de Witterberg, queria o debate e, talvez, jamais imaginou que a repercussão do fato de pregar suas 95 teses na porta da Igreja de Wittenberg culminasse com a Reforma Protestante.

A sucessão dos eventos foi avassaladora. Lutero contestava o poder centralizado do Papa Leão X e buscava, principalmente, o debate, o diálogo, a liberdade de culto e de consciência individual. Também combatia a ideia de que só os sacerdotes podiam interpretar o texto sagrado.

\footnotetext{
${ }^{4}$ Martinho Lutero (em Português) e Martin Luther (em Alemão).

5 A identidade espiritual da Ordem Agostiniana teve seu carisma ancorado na pessoa de Santo Agostinho, de quem recebeu o ideal sobre a vida religiosa, especialmente a importância da busca interior de Deus, da vida comum e da disponibilidade em servir a Igreja.
} 
O cenário econômico, político e geográfico europeu também estava mudado. $\mathrm{O}$ sistema feudal, autossuficiente e centralizado começava a ser contestado pelos mercadores, e as elites sociais queriam discutir a separação entre a Igreja e o Estado. Gradativamente, os feudos davam espaço geográfico para a formação dos Estados Nacionais, e os países emergentes exigiam autonomia.

Havia, portanto, um cenário de transformações que anunciava o fim da Idade Média, a entrada da Idade Moderna, ${ }^{6}$ e acenava para as novas ideias advindas do Iluminismo. Fechavase, também, um longo ciclo econômico, político e social da história da humanidade.

Lutero radicalizou as ideias de suas 95 teses, foi excomungado (Dieta de Worms, em 1521) e recebeu a proteção da realeza, especialmente, a alemã. O príncipe Frederico III, o Sábio, empreendeu uma emboscada, interceptou a carruagem e raptou o Reformador. Frederico III temia pela vida de Lutero após este ter desafiado o imperador Carlos V e o Papa Leão X, na Dieta de Worms, em não negar e retirar as 95 teses. Frederico III escondeu Lutero no Castelo de Wartburg, onde passou 10 meses escrevendo um texto bíblico que pudesse ser entendido por todos, criando uma tradução bem-sucedida que contribuiu decisivamente para o desenvolvimento da Língua Alemã na modalidade escrita. Nesse período, Lutero deixou crescer a barba e ficou conhecido como o Cavaleiro Jorge para as poquíssimas pessoas que o viram no Castelo de Wartburg (LINDBERG, 2017).

Com a invenção do tipo móvel por Johannes Gutenberg (1398-1468), estava aberta a possibilidade de impressão em grande escala e, por conseguinte, a difusão da leitura da Bíblia em Alemão. Para que as ideias avançassem pela Europa, era preciso que houvesse mais leitores, e isso alavancou os movimentos de alfabetização dos fiéis. O mundo foi mudando. E, romper fronteiras, buscar a emancipação humana do ser e do fazer, presença pública, ser cidadã, dizer a sua palavra foram princípios fundamentais da Reforma Protestante, e esse momento, trouxe, além de novas ideias, a abertura à arte e outras visões de mundo.

Assim, neste artigo, descreveu-se o contexto histórico e geográfico que permeou o evento da Reforma e, a partir do texto, buscou-se aliar as imagens e relacionar com o ensino de humanidades (Arte, História, Geografia e Filosofia), por meio da elaboração de um infográfico.

\footnotetext{
${ }^{6}$ A Idade Moderna ocorreu entre os séculos XV até XVIII. Seu início, segundo alguns historiadores, se deu no dia 29 de maio de 1453, data que registra a conquista turca de Constantinopla, e o final foi na Revolução Francesa de 14 de julho de 1789. Dentre os principais acontecimentos da Idade Moderna, citam-se: as Grandes Navegações, o Renascimento, a Reforma Protestante, o Absolutismo, a formação dos Estados Nacionais, o Iluminismo, o início da Revolução Francesa.
} 
A infografia alia texto e imagem a fim de transmitir uma mensagem visualmente atraente para o leitor, mas com contundência de informação na imagem. Isso significa que ela, a exemplo das fotos e dos títulos, é a porta de entrada para os textos, ou seja, é "ali que o leitor deposita, inicialmente, sua atenção e pode ser por meio deles que o leitor decida ler ou não a matéria" (SCALZO, 2005, p. 74).

Nesse contexto, o principal objetivo foi organizar o infográfico, 'Caminhos da Reforma', para apresentar o contexto geográfico e histórico da Reforma, na atual Alemanha, trazendo textos históricos e imagens atuais das Igrejas e das cidades importantes, a partir de Wittenberg, a Igreja do Castelo onde foram fixadas as 95 teses.

\section{Metodologia}

A metodologia está embasada no estado da arte, na perspectiva da pesquisa qualitativa que descreve a Reforma Protestante para o ensino de humanidades e no uso da cartografia para espacializar o contexto de vida do seu principal articulador, Martinho Lutero. O percurso do reformador foi delimitado no mapa a partir de informações bibliográficas, e as fotografias e os textos completaram o infográfico denominado 'Caminhos da Reforma'.

\section{Revisão de Literatura}

\subsection{O Contexto de Época}

A Baixa Idade Média (XIII até XV) foi caracterizada por transformações lentas, mas constantes, que provocaram crises no sistema vigente, que mostravam sinais de enfraquecimento e incapacidade de atender às necessidades espirituais e materiais de muitos setores populacionais. Surgiram insurgências e movimentos de revoltas populares que reivindicavam condições igualitárias e uma vida mais simples para os representantes do alto clero e da nobreza (LINDBERG, 2017).

Os movimentos revoltosos eram repreendidos duramente, e os líderes, considerados heréticos, eram executados em praça pública para denotar o medo entre os remanescentes. Apesar disso, novos pensamentos surgiam e ganhavam aceitação no meio acadêmico e nas relações comerciais. Assim, mais do que apenas um movimento religioso, a Reforma Protestante insere-se no contexto mais amplo que marcou a Europa a partir da Baixa Idade Média, expressando a superação da estrutura feudal tanto em termos de fé, como também nos aspectos políticos, econômicos e culturais (LINDBERG, 2017).

O ambiente europeu era o prelúdio de várias revoluções encenadas pelos novos contextos econômicos decorrentes do enfraquecimento do sistema feudal e da emergência de 
uma classe dedicada ao comércio, a burguesia. No cenário político, a centralização do poder e o monopólio da Igreja eram constantemente questionados nas cátedras, com o apoio de reis e da classe comercial emergente, a burguesia. O Renascimento traz o efeito de possibilitar a aceitação de conceitos e de visões diferentes daqueles que são ditados pelo poder teocrático.

Assim, a Reforma Protestante decorre, em parte, do Renascimento e ambos representaram uma adequação de valores e de concepções espirituais às transformações pelas quais a Europa passaria no âmbito social, econômico e político.

\section{Resultados e Discussões}

\subsection{Breve Descrição da Alemanha}

A República Federal da Alemanha é constituída de 16 Estados federados, chamados “Länder”. O Estado da Saxônia Anhalt, capital Magdeburg, é o principal cenário geográfico das cidades que compõem os lugares importantes no contexto histórico da Reforma.

A região da Saxônia Anhalt é a clássica Alemanha Central, banhada pelos rios Elba e Saale, que integra o maciço de Harz, uma rocha de 1.142 metros de altitude e o espinhaço de Fläming. É um Estado com baixa densidade demográfica, onde predomina a agricultura de cereais e vinhedos. Atualmente abriga modernos centros de pesquisa e centros da indústria química. Durante o período pós II Guerra Mundial até a queda do Muro de Berlim pertenceu àRepública Democrática Alemã (RDA), de economia socialista.

As principais cidades, com representação histórica, no contexto da Reforma Protestante, são as cidades de Wittenberg (na Igreja do Castelo Porta e de ferro da Igreja onde foram fixadas as 95 teses) e Lutherstadt Eisleben (cidade de nascimento e falecimento de Lutero) (figura 1). 
Figura 1: Mapa da República Federativa da Alemanha, o Estado da Saxônia Anhalt e a localização de Wittenberg e Lutherstadt Eisleben.

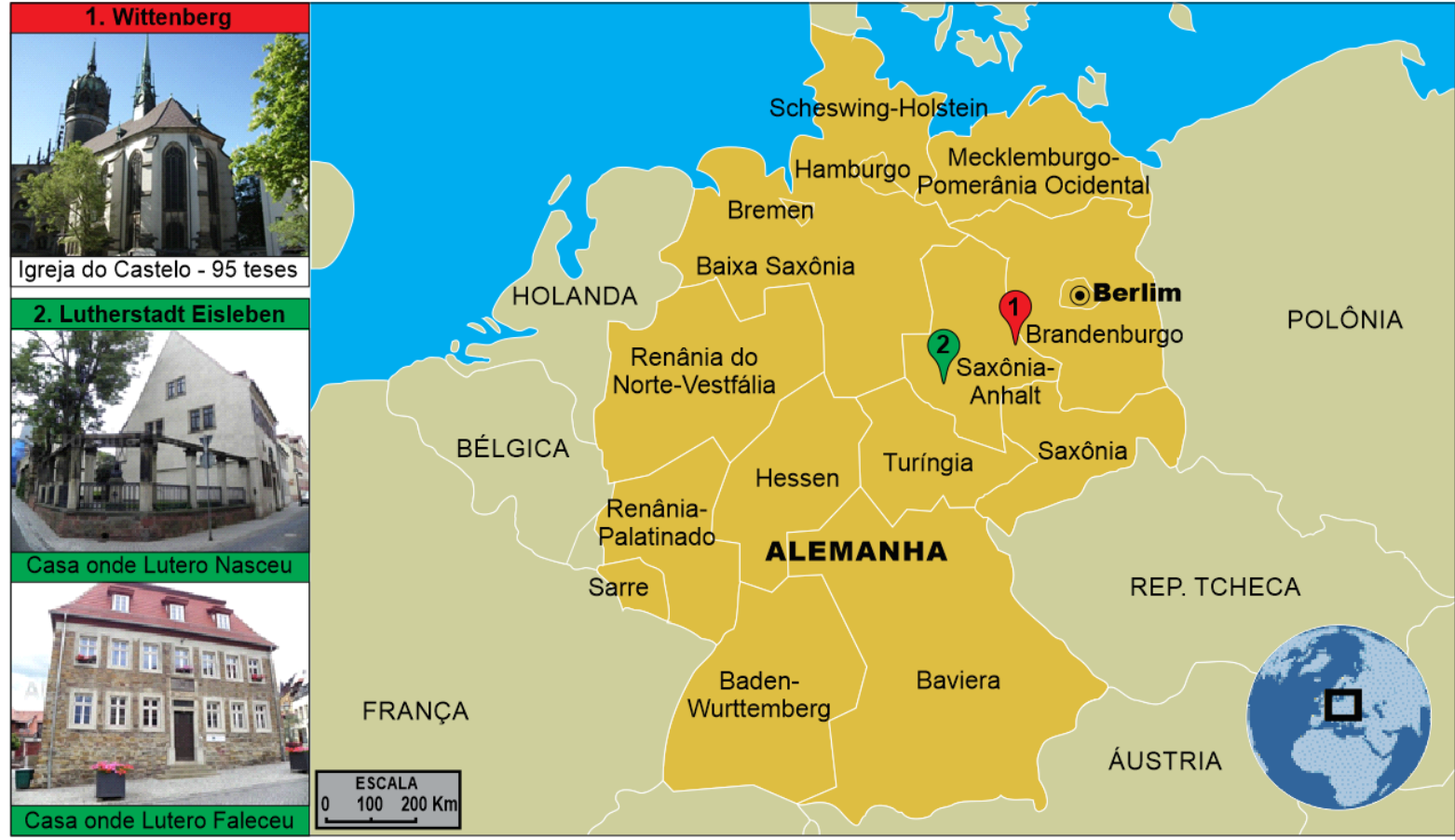

Fonte: Kappler, 2013.

\subsection{Contextualização do Infográfico 'Caminhos da Reforma'}

O texto apresenta o contexto geográfico e histórico da Reforma, na atual Alemanha, trazendo informações e imagens atuais das Igrejas e das cidades importantes da rota dos reformadores.

\subsubsection{Wittenberg, a cidade das 95 teses}

Em Wittenberg, na Igreja do Castelo (figura 2a), na porta de ferro (figura $2 b$ ) foram fixadas as 95 teses (figura 2c), em 31 de outubro de 1517. O nome oficial da cidade é Lutherstadt Wittenberg ou "Cidade de Lutero Wittenberg". Foi ali que teve início a Reforma Protestante. Consta que o reformador Martinho Lutero pregou as suas 95 teses contra o comércio de indulgências na porta da Igreja do Castelo de Wittenberg (BARRET, 2017). 
Figura 2: a) Igreja do Castelo; b) Porta de ferro da Igreja do Castelo; c) Ilustração de Lutero pregando as 95 teses na porta de ferro.

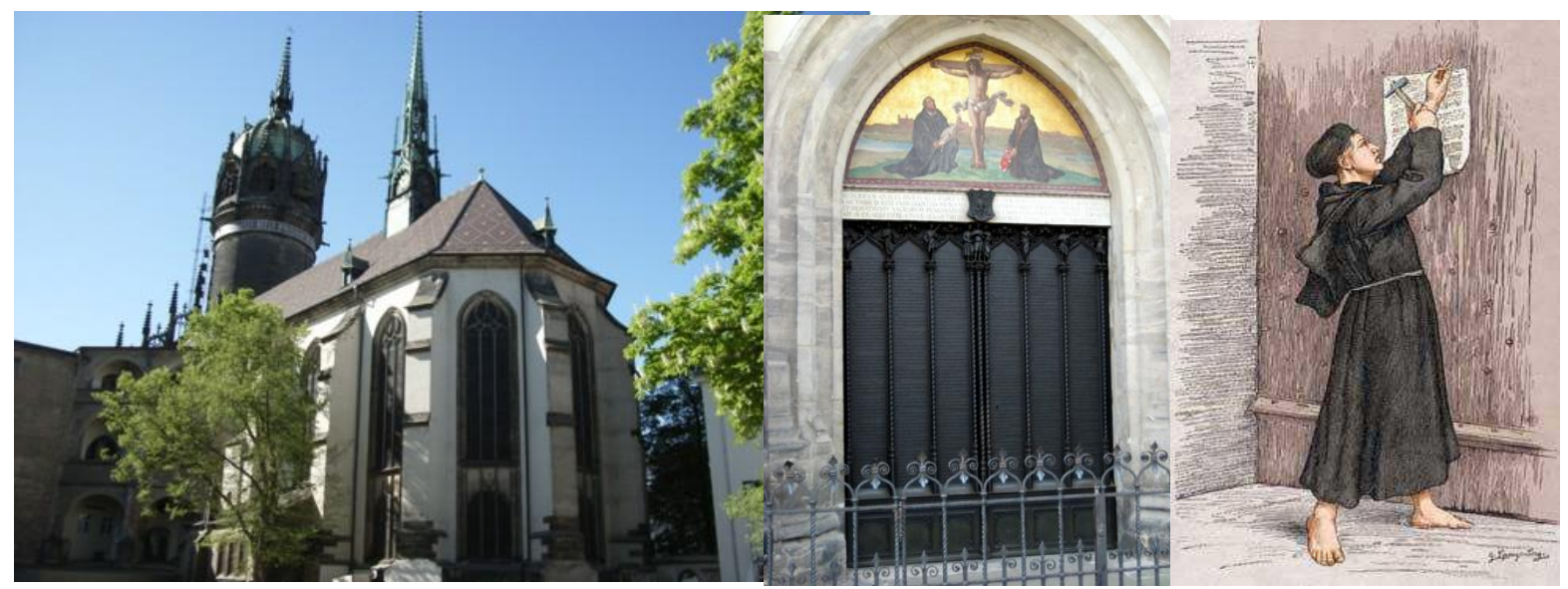

Fonte:

www.luteranos.com.br

\subsubsection{Lutherstadt Eisleben, a cidade de nascimento e morte de Lutero}

Outra cidade importante é Lutherstadt Eisleben, uma das mais antigas da Saxônia Anhalt, localizada entre as montanhas do Harz e o rio Elba, foi, na Idade Média, a sede dos Barões de Mansfeld. Durante os séculos XV e XVI, a mineração de cobre atraiu muitos trabalhadores para a cidade, então chamada apenas de Eisleben, entre eles, os pais de Lutero (LINDBERG, 2017).

Atualmente, a cidade é conhecida e visitada, sobretudo, como o local de nascimento e morte do mais importante reformador protestante alemão. Lutero nasceu em 10 de novembro de 1483, em Lutherstadt Eisleben ou "Cidade de Lutero Eisleben", segundo dos oito filhos de Hans Luther e Margareta Ziegler, família de origem camponesa e não muito afortunada. Foi batizado, no dia seguinte na Igreja de São Pedro e São Paulo e, conforme o costume da época, recebeu o nome do santo do dia, Martinho. Alguns meses depois, a família mudou-se para Mansfeld, porém, Lutero, durante toda a sua vida, manteve-se ligado ao seu local de nascimento e realizou muitos sermões da Reforma nas Igrejas de São Pedro e São Paulo, na Igreja de Santo André e na Igreja de Santa Anna. Os seus últimos quatro sermões foram na Igreja de Santo André, em um púlpito que ainda é preservado até a atualidade (LINDBERG, 2017).

Em sua última viagem, em 1546, Lutero foi como mediador para resolver um conflito envolvendo os Barões de Mansfeld e acabou falecendo em 18 de fevereiro de 1546, na casa da família Dragstedt (figura 3b), a qual foi transformada em museu. Ambas as casas, onde Lutero nasceu e a casa de morte, foram registradas, em 1996, na lista de Patrimônio da 
Humanidade pela UNESCO (LINDBERG, 2017). No centro da cidade, foi construída uma estátua de Lutero, na Praça do Mercado (Markplatz) (figura 3c).

Figura 3: a) Casa de nascimento de Lutero; b) Casa de falecimento; c) Markplatz.

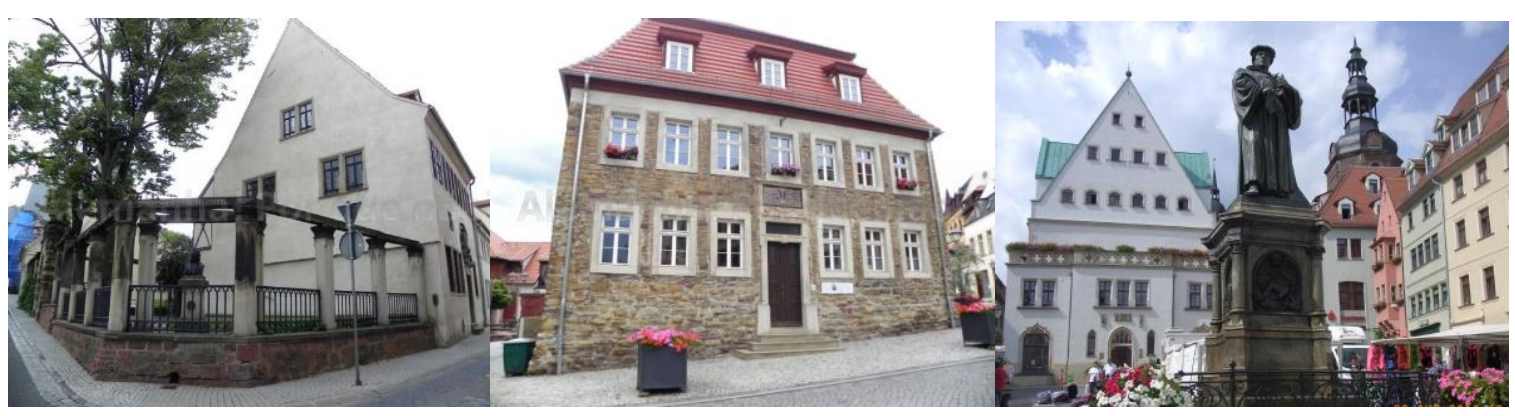

Fonte: www.luteranos.com.br

\subsubsection{Mansfeld, a cidade da infância de Lutero}

Mansfeld é uma típica cidade do interior da Alemanha (figura 4), localizada a, aproximadamente, 10 quilômetros de Lutherstadt Eisleben que, na época, atraiu muitos trabalhadores para as ricas minas de cobre. O pai de Lutero trabalhou nas minas de cobre, e Mansfield foi a cidade em que viveu a sua infância. Hoje, na antiga cidade de mineração, existe o único Museu Lutero dedicado à infância do reformador. Os pais de Lutero moraram na cidade de 1484 a 1497, e, de 1488 a 1496, o reformador frequentou ali a escola. Em 1497, Lutero estudou na escola de Magdeburg, a principal cidade da Saxônia Anhalt (LINDBERG, 2017).

Figura 4: Mansdeld, a cidade da infância de Lutero.

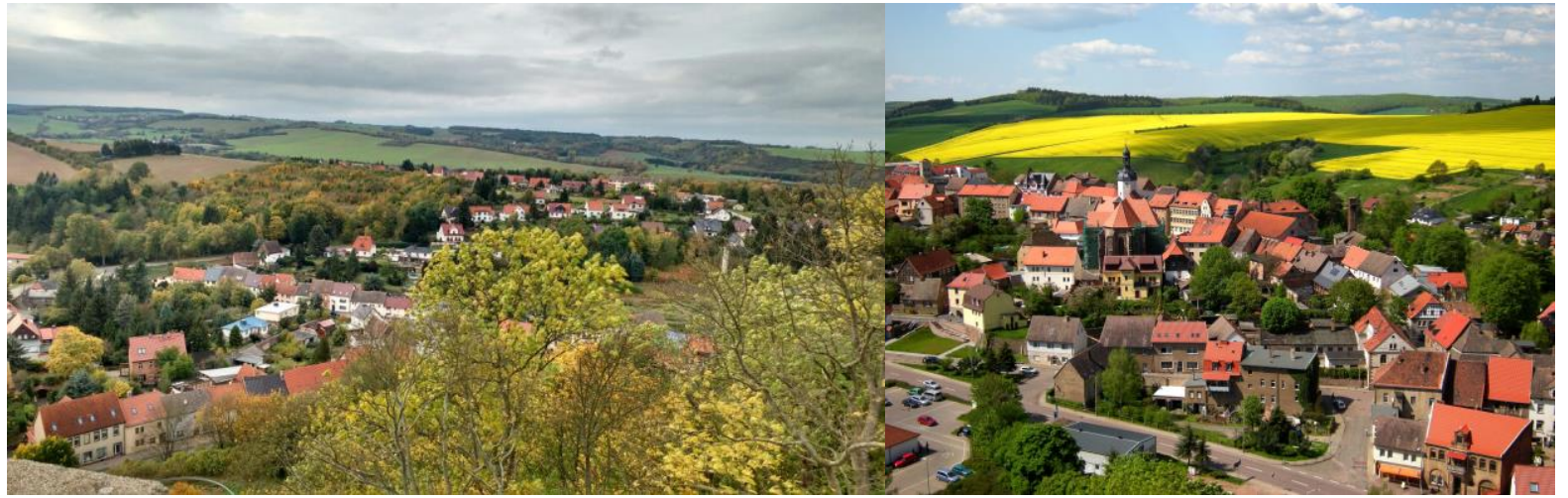

Fonte: Kappler, 2013.

\subsubsection{Halle, 'berço intelectual da Reforma'}

Halle (Saale) é considerada a cidade 'berço intelectual da Reforma'. Localiza-se no Estado da Saxônia Anahlt e é a maior cidade desse Estado, distando cerca de 150 quilômetros de Berlim. Lutero realizou três sermões na Igreja do Mercado em Halle. Atualmente, a cidade 
abriga a Universidade Martinho Lutero, em Halle-Wittenberg (figura 5), que surgiu da fusão de duas instituições acadêmicas, a de Wittenberg, fundada em 1502, e a de Halle, fundada em 1694. Em Wittenberg, lecionavam Martinho Lutero e outros importantes pensadores da Reforma e, em decorrência disso, a cidade e sua universidade tornaram o centro da Reforma Protestante. A Universidade de Halle tornou-se o ponto de partida do Renascimento alemão a partir de filósofos renascentistas como Christian Wolff (LINDBERG, 2017).

Figura 5: Universidade Martinho Lutero em Halle-Wittenberg.

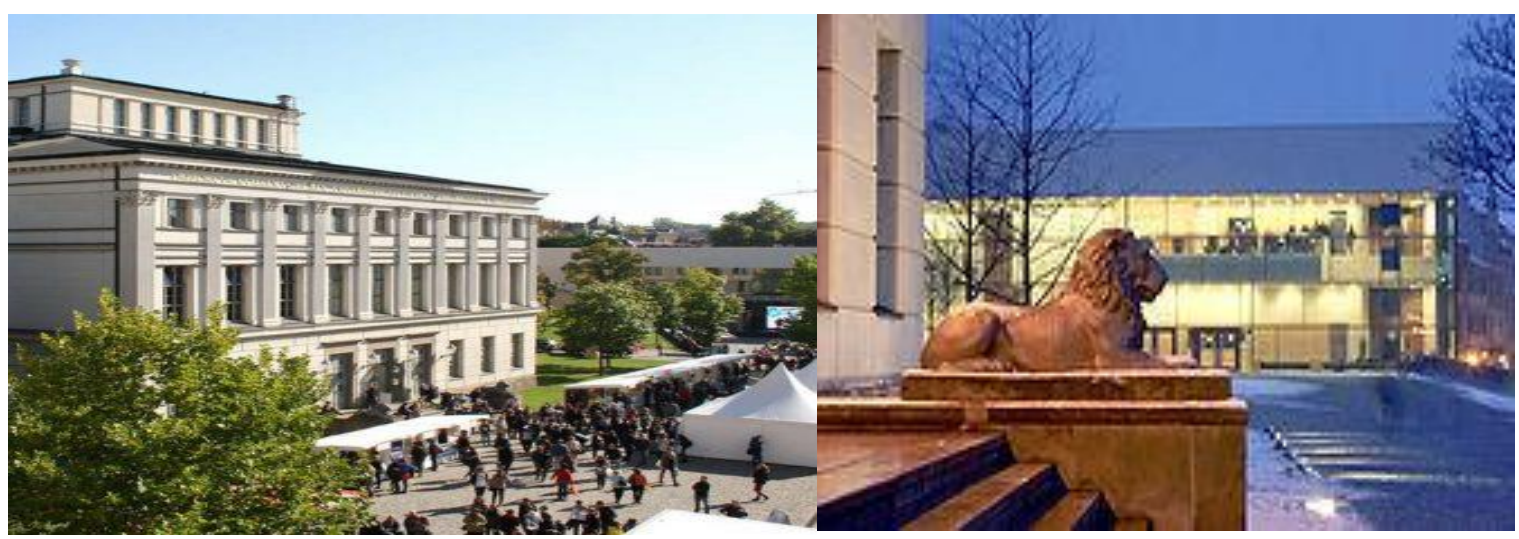

Fonte: Kappler, 2013.

\subsubsection{Leipzig, um ponto de pregação dos reformadores}

A cidade de Leipzig (figura 6a) localiza-se no Estado da Saxônia, ficou na rota dos reformadores e tornou-se um importante ponto de pregação e de debate, especialmente, na Igreja de São Thomas (figura 6b). A Igreja e a cidade também marcam importância na vida e na obra de Johann Sebastian Bach (1685-1750) que, em maio de 1723, vai trabalhar como diretor musical e compõe a maior parte de suas obras, a 'Missa em Si Menor' e as duas paixões mais conhecidas, as composições de São João e a de São Matheus (RUEB, 2001). 
RELACult - Revista Latino-Americana de Estudos em Cultura e Sociedade

Revista Latinoamericana de Estudios en Cultura y Sociedad | Latin American Journal of Studies in Culture and Society V. 04, ed. especial, fev., 2018, artigo n 672 | relacult.claec.org | e-ISSN: 2525-7870

Figura 6: a) Vista parcial da cidade de Leipzig; b) Igreja de São Thomas, em Leipzig.

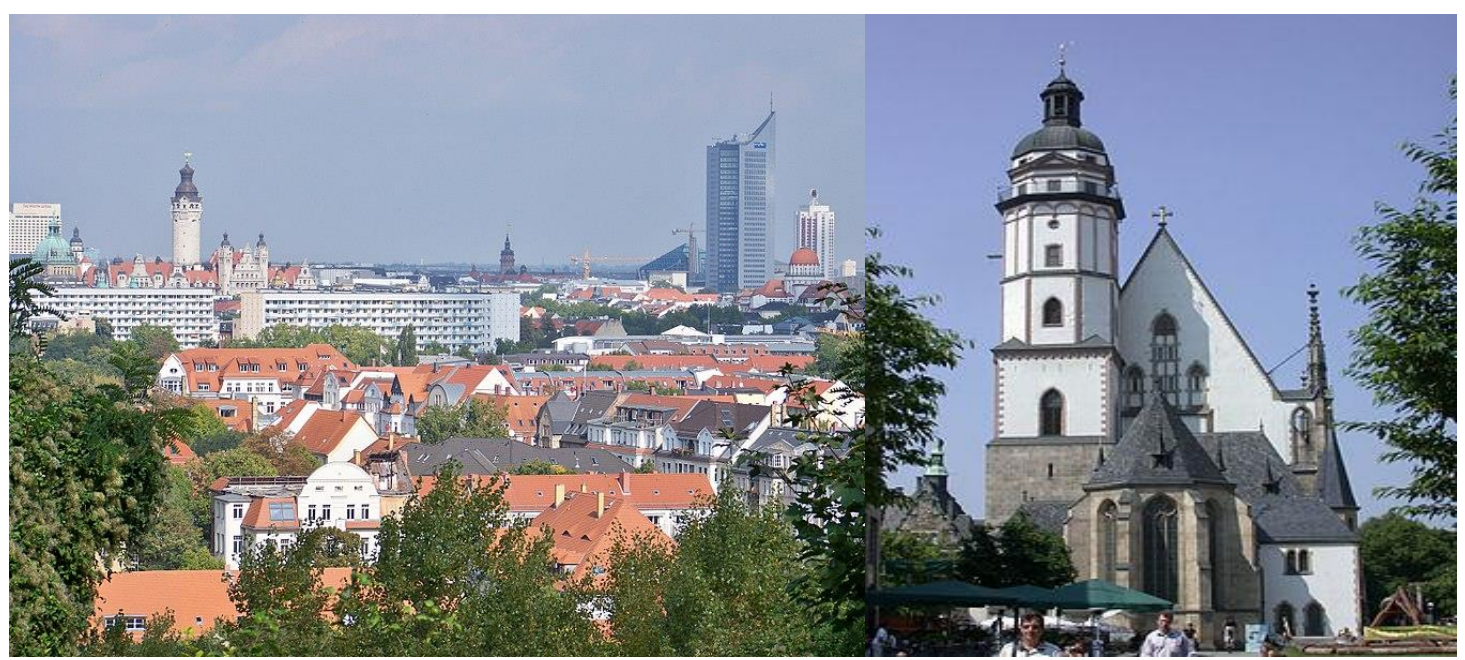

Fonte: Kappler, 2013.

\subsubsection{Naumburg, um ponto na rota do protestantismo}

A cidade de Naumburg (figura 7a) foi um marco na rota do protestantismo, e a Catedral de Naumburg, um importante ponto de pregação e de debate dos reformadores. A Catedral foi construída entre os séculos XIII e XIV e constitui a obra arquitetônica mais importante até os dias atuais com traços de estilo gótico e influência do romantismo (figura 7b) (LINDBERG, 2017).

Figura 7: a) Vista parcial da cidade de Naumberg; b) Catedral de Naumberg, com estilo arquitetônico gótico e influência do romantismo.

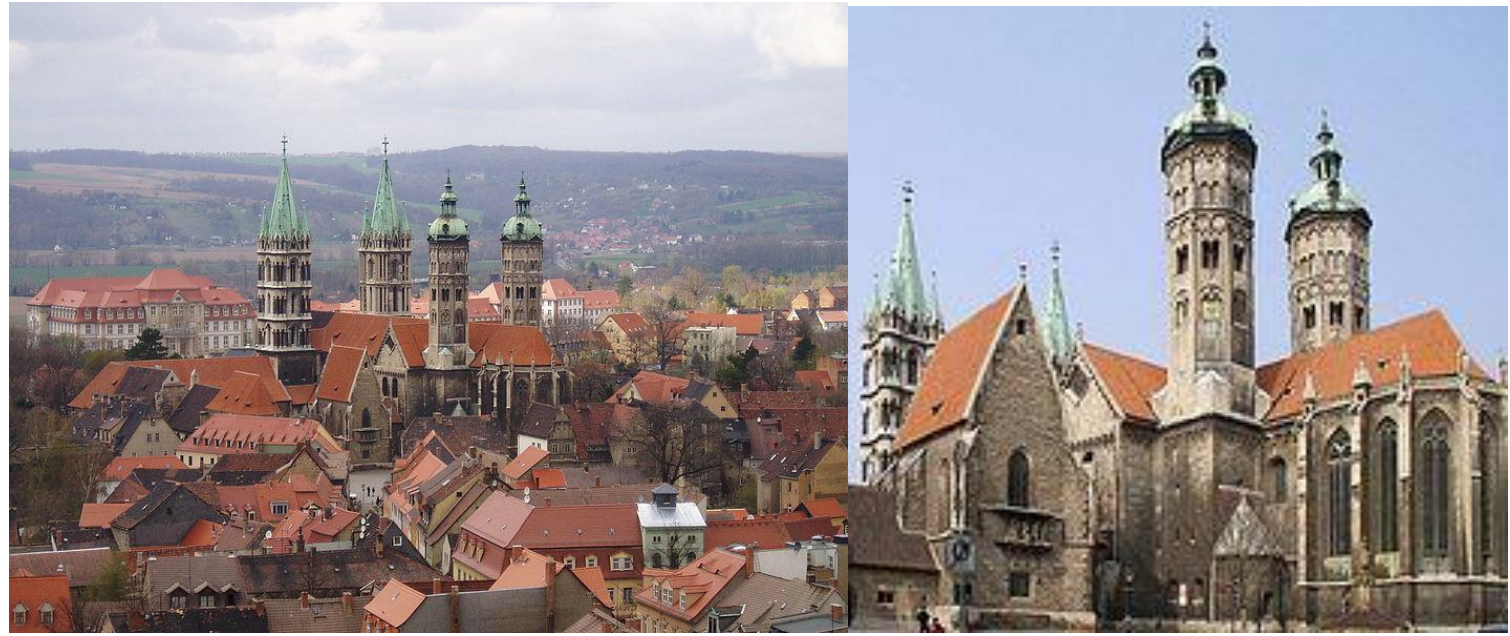

Fonte: Kappler, 2013. 


\subsubsection{Weimar e a Praça do Mercado, um local de encontro dos reformadores}

Weimar é uma cidade histórica alemã, considerada a capital da cultura do país. A praça do Mercado (Marktplatz) abriga uma feira de flores e verduras, e o prédio, de 1841, abriga, atualmente, a Prefeitura. No período da Reforma, foi um importante local de encontro dos reformadores (11).

Figura 11: Mercado de Weimar foi um ponto de encontro dos reformadores.

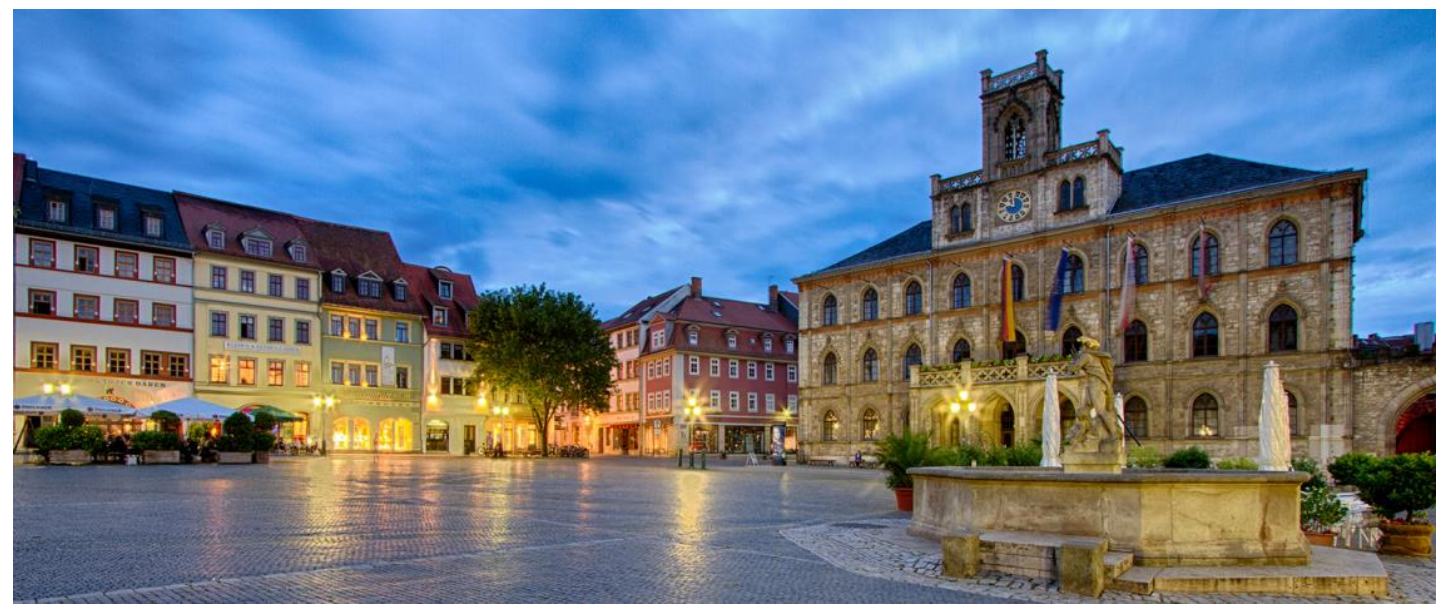

Fonte: Kappler, 2013.

\subsubsection{Erfurt e os estudos de Lutero na Universidade}

Na cidade de Erfurt (figura 9a), capital do Estado alemão da Turíngia, Lutero iniciou os estudos na Universidade de Erfurt, em 1501 até 1505, e realizou pesquisas em "Artes Livres" como gramática, retórica, fillosofia, matemática, astronomia (LINDBERG, 2017).

Em 1505, recebe o título de Mestre em Artes e, após, inscreve-se na Faculdade de Direito a pedido do pai, porém uma tempestade, no dia 2 de julho de 1505, e o temor dos raios levaram-no a fazer a promessa de se tornar monge. Quinze dias depois, ingressa no Convento dos Eremitas Agostinianos de Erfurt (figura 9b) e, em 1507, é ordenado monge agostiniano, no dia 4 de abril, e, no dia 2 de maio, Lutero celebra a sua primeira missa (LINDBERG, 2017).

Em 1508, leciona filosofia moral na Universidade de Wittenberg e, ao mesmo tempo, prossegue seus estudos de teologia, tornando-se bacharel no ano seguinte e continua seus trabalhos como monge no mosteiro agostiniano. Em 1509, leciona, também, dogmática no Estudo Geral da Ordem. Em 1510, viaja a Roma para tratar de assuntos da Ordem Agostiniana e retorna em 1511, quando é transferido definitivamente para Wittenberg, onde assume uma cátedra (LINDBERG, 2017). 
O Mosteiro Protestante Agostiniano em Erfurt tem estilo arquitetônico das ordens religiosas na Idade Média e é um importante centro nacional e internacional da Reforma Protestante.

Figura 9: a) A cidade de Erfurt e a Igreja de São Nicolau; b) Mosteiro Protestante Agostiniano em Erfurt.

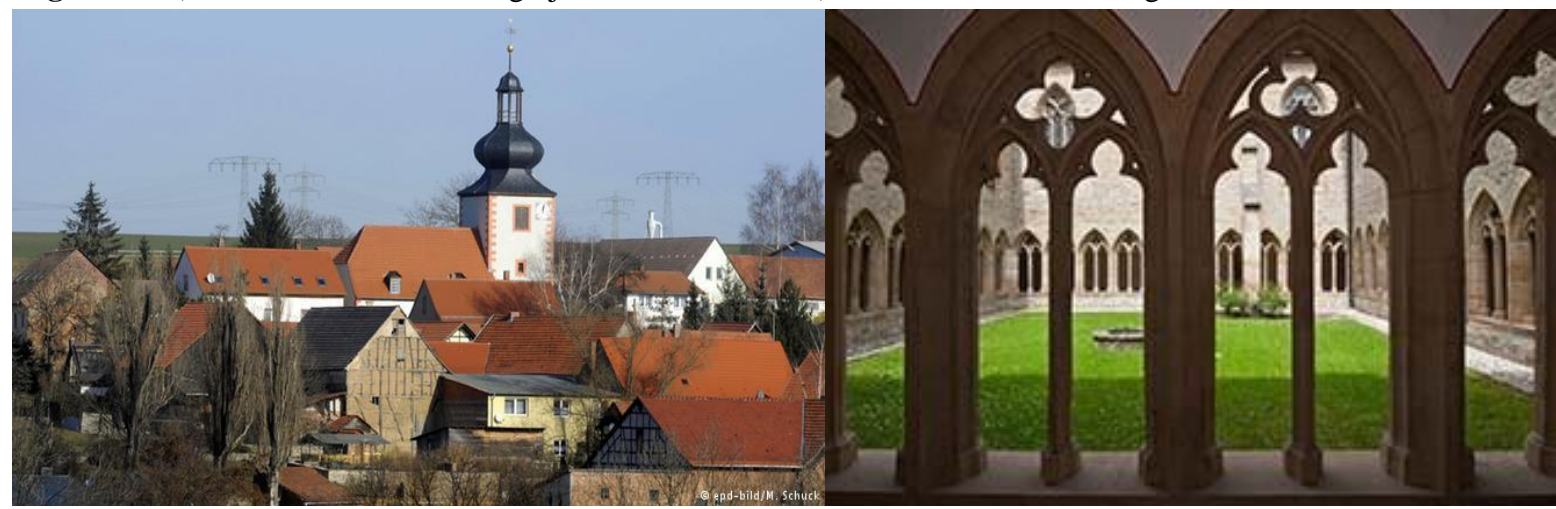

Fonte: Kappler, 2013.

\subsubsection{Eisenach, a cidade do refúgio de Lutero}

A cidade de Eisenach localiza-se no Estado da Turíngia (sudoeste do Estado da Saxônia Anhalt). Preserva um cenário importante da vida do Reformador que ali viveu parte de sua infância e, também, parte da sua vida adulta.

A geografia local é emblemática, formada de vales e colinas, que ostentam árvores da Floresta Temperada, localmente, denominada de Floresta da Turíngia. A cidade foi fundada na parte mais alta do terreno, no século XII, e, desde então, foi palco da história de senhores feudais. É, também, a cidade natal de Johann Sebastian Bach (1686-1750) (RUEB, 2001).

Lutero estudou na escola em Eisenach entre 1498 e 1501. Seu pai, Hans, consegue enviar o filho para estudar em Eisenach por ter, nesta cidade, algumas relações de amizade e Lutero é recebido na casa da família Ursula Cotta. Para custear os estudos do filho, o pai tocava em serenatas. Em 1956, a Igreja Luterana da Turíngia abriu no prédio um museu eclesiástico como memorial ao reformador (figura 10a) (LINDBERG, 2017).

Eisenach, mais tarde, seria a cidade do refúgio de Lutero, quando recebeu a proteção de Frederico III, o Sábio, após ter sido desafiado pelo imperador Carlos V e o Papa Leão X, na Dieta de Worms. Foi nesse período, 1521, no Castelo de Wartburg (figura 10b), que Lutero traduziu a Bíblia (o Novo Testamento) do Latim para a Língua Alemã (figura 10c). A tradução é considerada responsável pelo surgimento da Língua Alemã Moderna. Nesse período, Lutero deixou crescer a barba e ficou conhecido como o Cavaleiro Jorge para as poquíssimas pessoas que o viram no Castelo de Wartburg. Desde 1999, o Castelo de Wartburg é Patrimônio da Humanidade e está aberto à visitação (LINDBERG, 2017). 
Figura 10: a) Casa onde Lutero morou na infância, atualmente é um Museu Eclesiástico; b) Castelo de Wartburg; c) Quarto e mesa onde Lutero traduziu o Novo testamento para a Língua Alemã no Castelo de Wartburg.

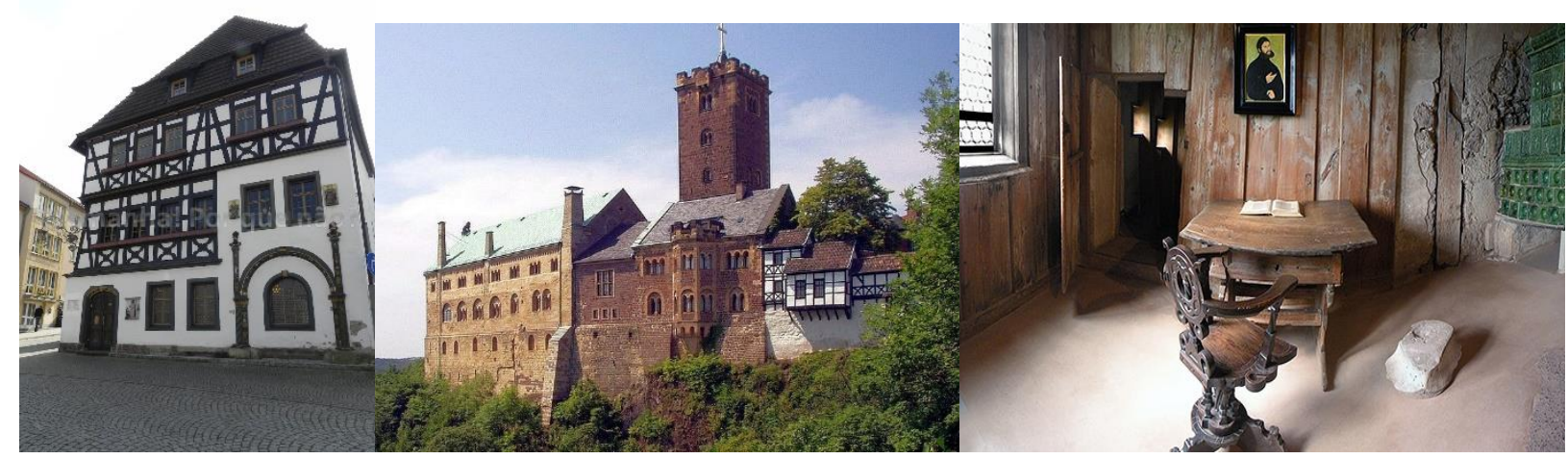

Fonte: Kappler, 2013.

\subsubsection{Frankfurt e a Igreja de São Paulo como sede do primeiro parlamento alemão}

Frankfurt (figura 11a) é a maior cidade do Estado alemão de Hesse. A Igreja de São Paulo, a Paulskirche (figura 11b), não foi palco da história de Lutero, mas tem grande importância para todos os alemães. É uma igreja luterana do século XIX e foi sede do primeiro parlamento alemão e, por isso, é um Monumento Histórico da nação alemã e com grande simbolismo político.

O prédio foi construído entre 1789 e 1833 e utilizado como igreja protestante até ser lugar de reuniões do parlamento, em 1848. Em 1852, a igreja voltou a ser centro de encontros religiosos. Durante a Segunda Guerra Mundial, como aconteceu com toda a cidade, a Paulskirche foi totalmente destruída. Mais tarde, foi reconstruída e reinaugurada no centenário do Parlamento de Frankfurt, em 1948, sendo o primeiro edifício a ser reconstruído pós-guerra. Atualmente, o prédio não é mais utilizado para fins religiosos, mas para eventos, exposições e para turismo (LINDBERG, 2017).

Figura 11: a) Vista parcial da cidade de Frankfurt, no Estado de Hesse; b) Igreja de São Paulo, sede do primeiro Parlamento do Estado Alemão.

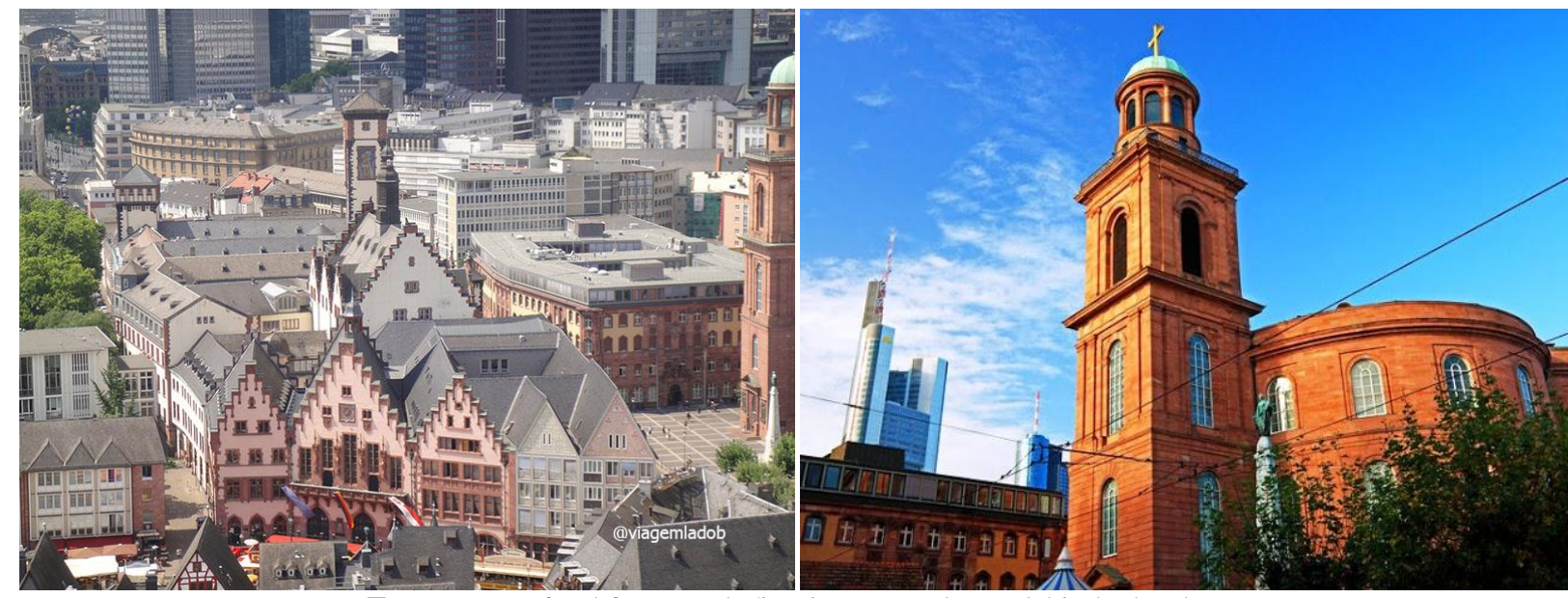

Fonte: www.frankfurt.com.br/igreja-sao-paulo-paulskirche.html 


\subsubsection{Heidelberg, um ponto de debates}

A cidade de Heidelberg localiza-se em Baden-Wüttenberg, a cerca de $120 \mathrm{~km}$ a noroeste da capital do Estado, Stuttgart. É uma cidade muito antiga que preserva traços celtas e resquícios da ocupação romana. Atualmente, Heidelberg ainda se traduz no romantismo idílico entre as imponentes arquiteturas de seus antepassados e sua paisagem natural ornada pela presença do rio Neckar e as encostas da floresta de Odenwald.

Em 1518, Lutero viajou a Heidelberg para um debate com monges agostinianos, do qual resultou forte influência das ideias reformistas na região de Heidelberg. A Igreja do Espírito Santo de Heidelberg ou Heiliggeistkirche, em estilo gótico, fica na Praça do Mercado (Marktplatz), na Altstadt (Cidade Velha). Atualmente, é uma igreja Protestante, mas que passou por períodos, no passado, em que era compartilhada por Protestantes e Católicos (LINDBERG, 2017).

Figura 12: a) Vista parcial da cidade de Heidelberg; b) Vista da Igreja do Espírito Santo em Heidelberg.

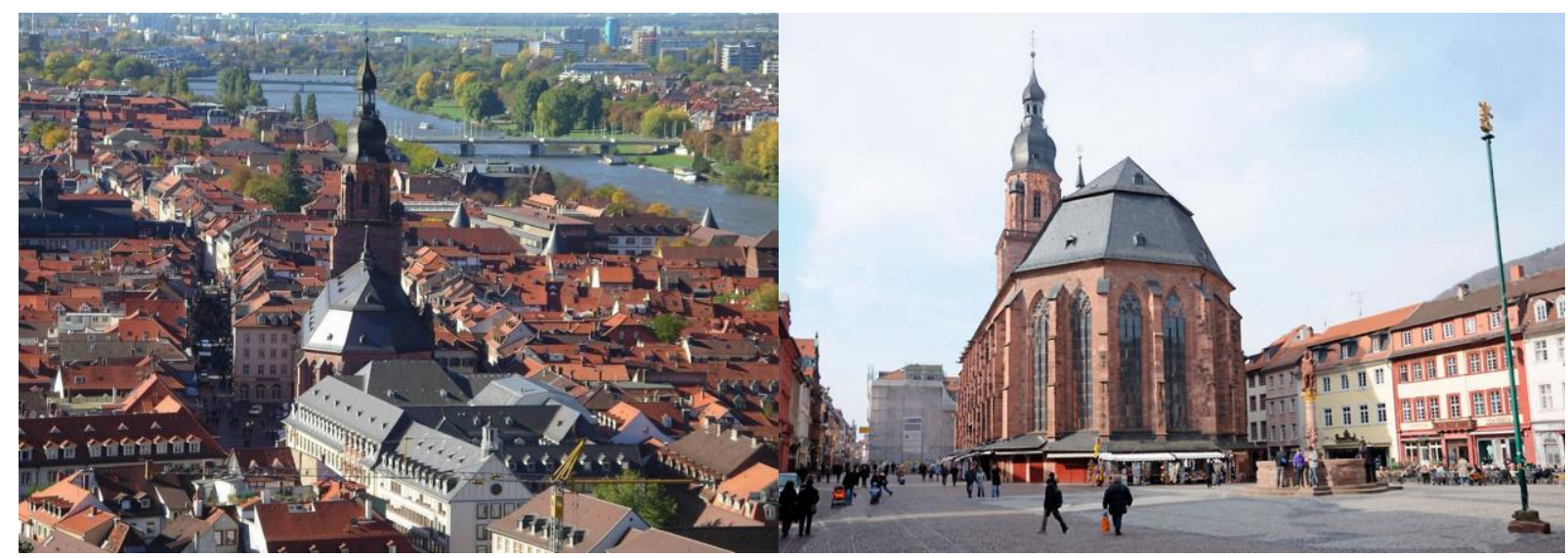

Fonte: https://pt.depositphotos.com〉fotografias $>$ arquitetura\&edifícios

\subsubsection{Worms, o local da Dieta de Worms}

No sudoeste da Alemanha, no Estado da Renânia-Palatinado, localiza-se a cidade de Worms (figura 13a), que é conhecida por ter sediado, em 28 de janeiro de 1521, uma assembleia, convocada pelo imperador Carlos V, para julgar Martinho Lutero por crimes cometidos contra a Igreja Católica. A assembleia ficou conhecida como a Dieta de Worms (figura 13b) e foi convocada pelo Papa Leão X que, desde 1520, estava incomodado com a repercussão das 95 teses de Lutero. O Papa Leão X, o príncipe Carlos V e o Conselho de Worms exigiram a retratação de Lutero, sob pena de sua excomunhão. Lutero não se retratou e manteve as severas críticas, especialmente, contra a cobrança de indulgências (salvação) e à simonia (vendas de artigos religiosos falsamente sagrados) o que instaurou uma crise que abalou os pilares da Igreja Católica. Lutero foi considerado herege, foi excomungado e 
perseguido e viveu foragido no Castelo de Wartburg, na cidade de Eisenach, no estado da Turíngia (BARRET, 2017).

Figura 13: a) Vista parcial da cidade de Worms; b) Ilustração da Assembleia de Worms, no centro, Lutero; ao redor, os membros clericais e príncipes alemães e, à direita, Carlos V.

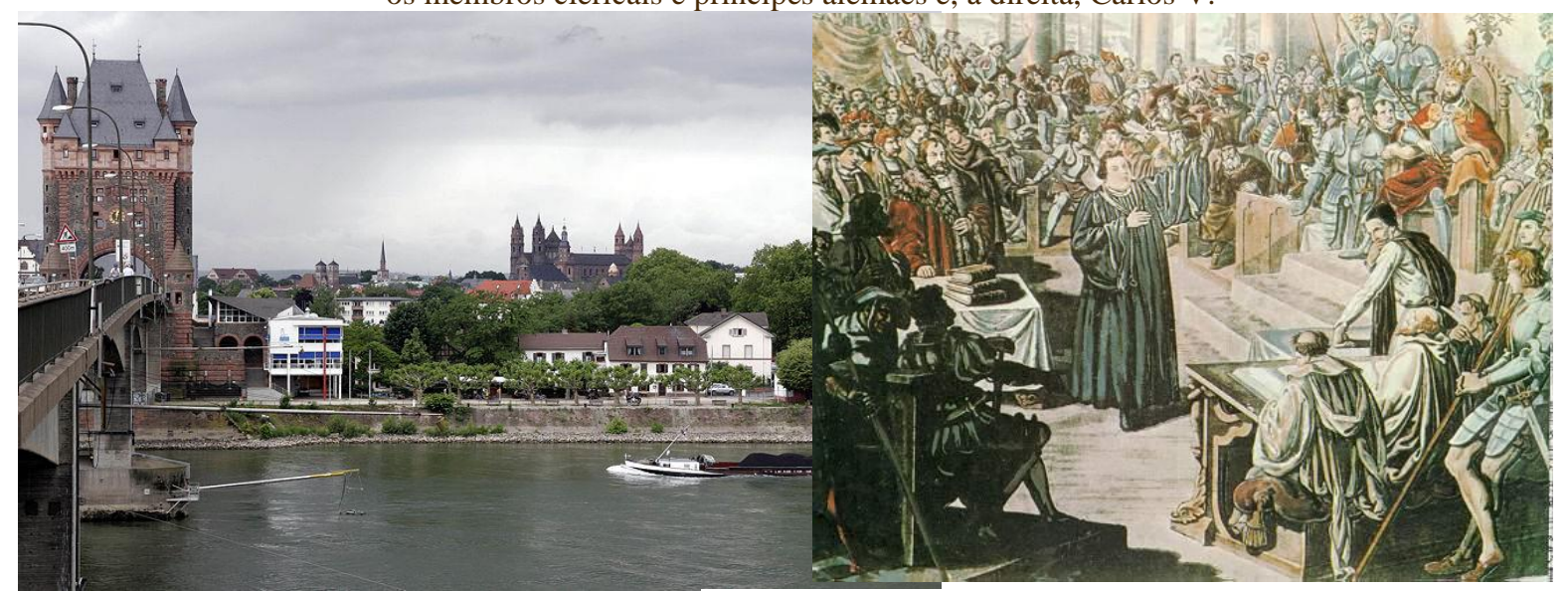

Fonte: www.luteranos.com.br

\subsubsection{Speyer e a catedral em estilo românico}

Speyer (figura 14a) é uma cidade localizada no Estado da Renânia Palatinado e foi fundada pelos romanos. A principal catedral de Speyer (figura 14b), em estilo arquitetônico romano, integra os monumentos culturais de UNESCO (Organização das Nações Unidas para a Educação, a Ciência e a Cultura). A cidade e a catedral de Speyer foram importantes no contexto da Reforma quando um grupo de príncipes se reuniram para assinar um protesto contra a Dieta de Worms que, entre outros procedimentos, proibiu os ensinamentos luteranos no Sacro Império Romano-Germânico (LINDBERG, 2017).

Figura 14: a) Vista parcial da cidade de Speyer; b) Catedral de Speyer

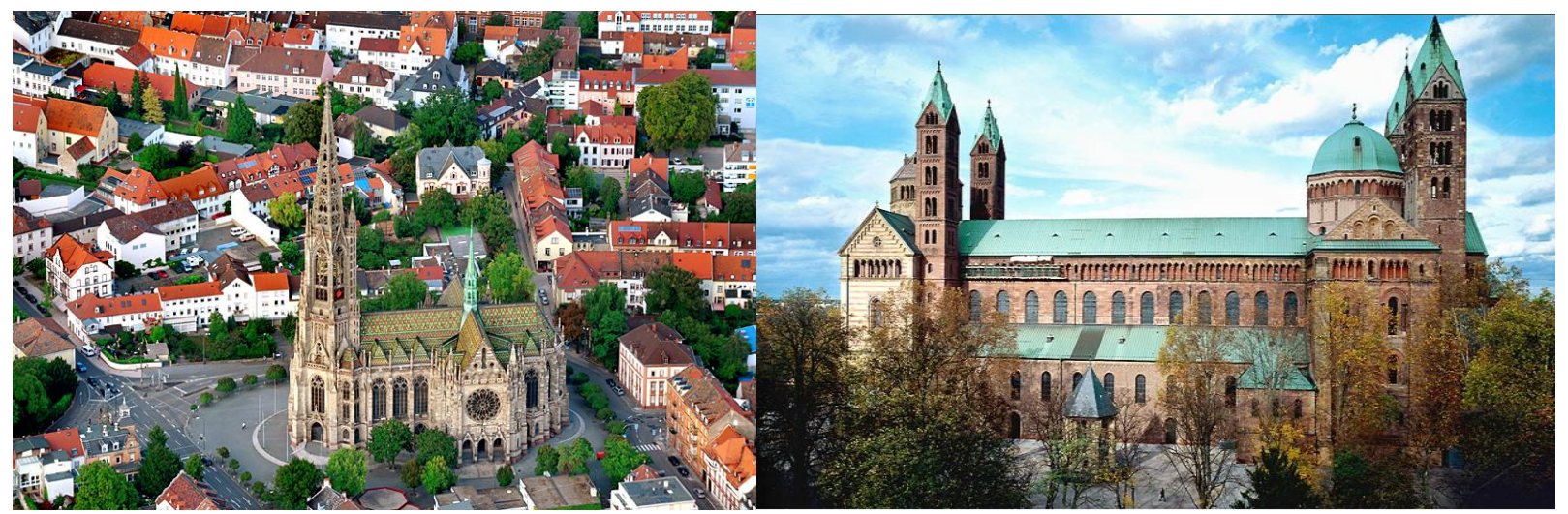

Fonte: Kappler, 2013. 


\subsubsection{Torgau, uma importante cidade}

É uma cidade banhada pelo rio Elba (figura 15a), no Estado alemão da Saxônia, e, no contexto do século XIV, sediava a residência dos príncipes-eleitores e, por isso, Martinho Lutero era presença frequente ali. Em 1544, ele inaugurou a primeira capela protestante no Castelo Hartenfels (figura 15b) (LINDBERG, 2017).

Figura 15: a) Rio Elba em Torgau; b) Castelo Hartenfels, a primeira capela protestante de Torgau.

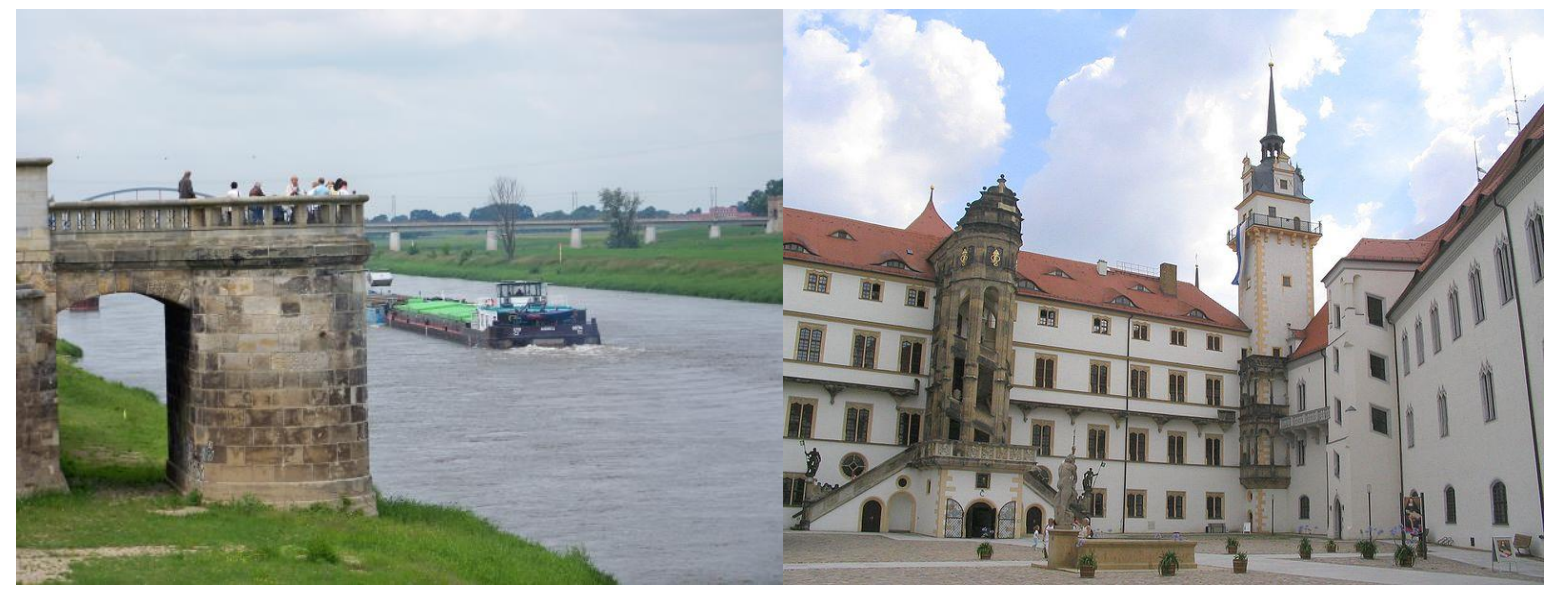

Fonte: Kappler, 2013.

\subsection{O infográfico 'Caminhos da Reforma'}

O infográfico, 'Caminhos da Reforma', apresenta as imagens atuais das Igrejas e das cidades importantes da rota dos reformadores. 
Figura 16: Infográfico 'Caminhos da Reforma'.

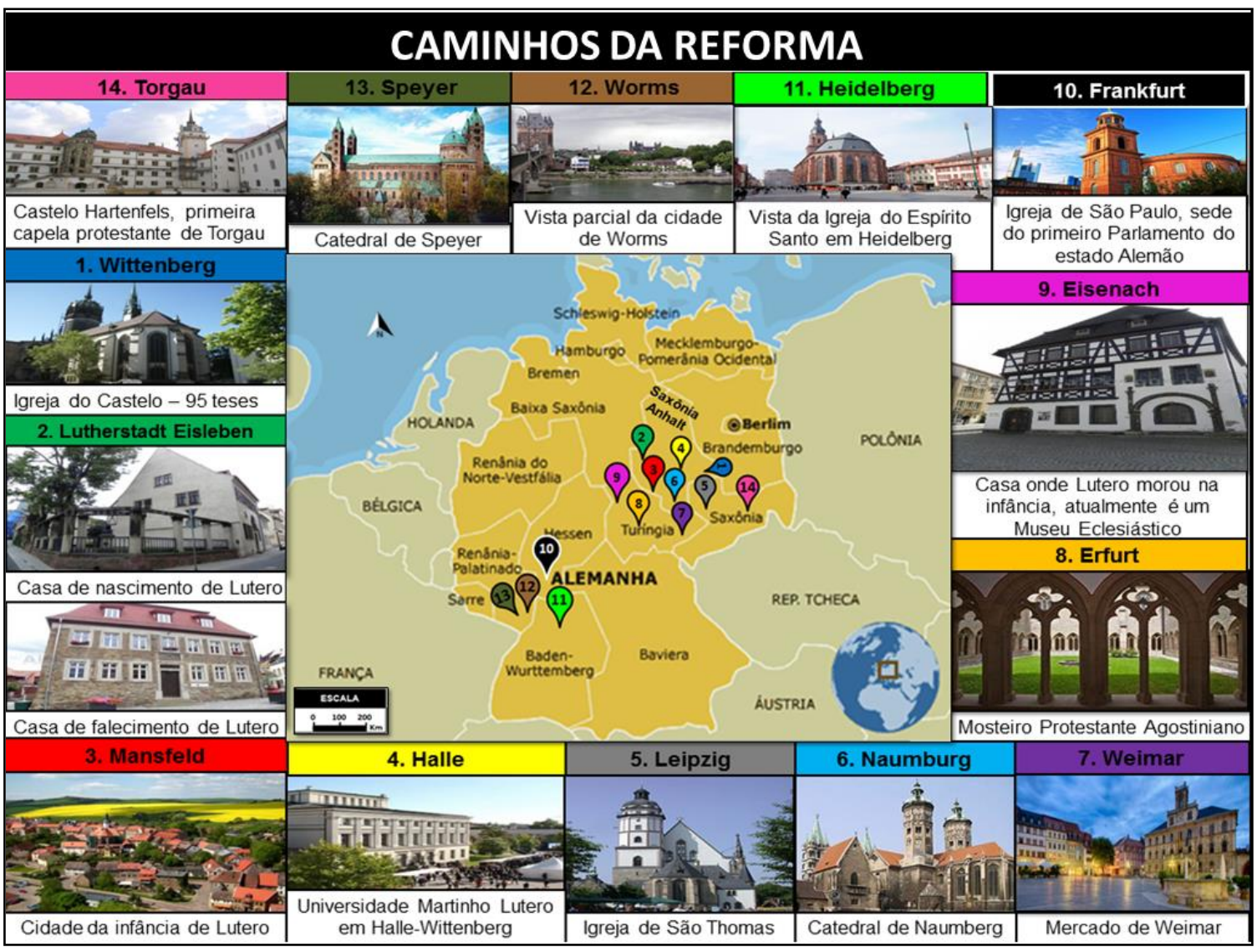

Fonte: https://www.google.com.br/search?q=mapa+da+alemanha\&tbm (adaptado).

\subsection{O legado da Reforma no mundo atual}

O conjunto de textos e imagens retratam os locais significativos no percurso da história protestante e evidencia um contexto de mudança no pensamento dominante. As mudanças que se engendraram a partir do cisma foram irreversíveis na política e na sociedade do Sacro Império Romano-Germânico.

As contestações de Martinho Lutero abalaram a secularização dos dogmas da Igreja Católica e abriram caminho para indagações na estrutura política dominante.

Cinco séculos depois, 2017, a Alemanha, herdeira direta da Reforma Protestante, mostra-se ativa e mantém vivo o espírito de mudança instaurado, em 1517, pelo jovem monge Lutero.

O fim do celibato, o perdão pela fé e a popularização da Bíblia fizeram parte da doutrina luterana desde o rompimento com o Vaticano. Nessa trajetória, a Igreja Luterana da Alemanha (EKD) ${ }^{7}$ acompanha os temas e as mudanças sociais e culturais emergentes na pósmodernidade e aceitou reivindicações que ainda são tabus em algumas esferas da sociedade.

\footnotetext{
${ }^{7}$ EKD - Evangelische Kirche in Deutschland.
} 
A primeira grande mudança ocorreu no fim da década de 1940 com a abertura para a ordenação de mulheres e em 2015 as mulheres já totalizaram 33\% dos ordenados. Embora aceitasse pastoras, o caminho foi longo até a nomeação da primeira bispa, que ocorreu em 1992. Atualmente, a EKD promove uma campanha de equiparação de gênero em todos os níveis da Instituição (AQUINO, 2016).

A ordenação de mulheres é uma consequência da teologia de batismo de Lutero. Para ele, todo cristão batizado pode ser padre, bispo e até para. Então, essa premissa é válida para as mulheres (AQUINO, 2016).

Além de buscar a equiparação entre gêneros, a EKD deu um passo importante para combater o preconceito contra o homossexualismo. A Instituição publicou novas diretrizes para o modelo familiar e passou a considerar uma família qualquer núcleo onde haja amor, deixando de lado o tradicional "pai e mãe casados com filhos" e aceitando parceiros do mesmo sexo. Ao justificar as novas diretrizes, a EKD lembrou que padrões tradicionais eram contestados há anos e essa luta havia alcançado mudanças sociais e legais que reconheceram a diversidade familiar e a igualdade de direitos entre os membros de diferentes constelações familiares. Já no caso do casamento entre homossexuais, a aceitação religiosa veio bem antes da legal. Desde 2013, as comunidades regionais da EKD começaram a aprovar e realizar o matrimônio homoafetivo. O Parlamento Alemão viria legalizar o casamento gay somente em 2017 (BARRET, 2017). A Igreja da Reforma procura seguir o legado de Lutero e busca se transformar continuamente, aprendendo com as inovações e com os novos desafios da sociedade pós-moderna.

\section{Conclusões}

O contexto da Europa na época da Reforma aponta para a decadência da Idade Média a partir de várias transformações que estavam em curso e cuja importância não podem ser desassociadas da Reforma emergente na Igreja Cristã Romana. As mudanças para o Velho Mundo ficaram ainda mais acentuadas com a descoberta do Novo Mundo por Colombo e Cabral.

A ideia de uma terra 'centro do universo' foi cedendo lugar a indagações e à novas formulações de pensamentos. Também a ideia de um poder centralizado foi enfraquecido pela emergência do conceito de estado-nação. Com a formação das cidades, a economia comercial tomou o lugar da feudal e, com isso, surgiu e se fortaleceu uma nova classe social, a burguesia. Também no campo da cultura e da arte, com o surgimento do Renascimento, as transformações intelectuais fizeram com que as ideias de Lutero encontrassem respaldo nas 
cátedras e o pensamento dominante foi mudando e adquirindo novas formas de ver e de interpretar o mundo.

Nesse sentido, a Reforma Protestante representou uma mudança e uma adequação de valores e de concepções espirituais às transformações pelas quais a Europa passaria no âmbito social, econômico e político. E esse cenário é um importante contexto de debate para jovens estudantes do Ensino Médio. Assim, o infográfico 'Caminhos da Reforma' destina-se para estudantes do Ensino Médio, como um recurso multimodal que alia texto, mapa e imagens, e serve de motivação para o ensino em ambientes formais e não-formais.

Pode-se considerar que as imagens, nos infográficos, por estarem no primeiro nível de leitura, chamam a atenção dos estudantes para a matéria, convidando-os, deste modo, para a leitura. Além disso, a valorização das imagens torna o infográfico, também, acessível a qualquer tipo de público.

\section{Referências}

AQUINO, F. Para entender a Reforma. São Paulo: Cleófas, 2016.

BARRET, M. Teologia da Reforma. São Leopoldo: Sinodal, 2017.

DELUMEAU, J. Nascimento e Afirmação da Reforma. São Paulo: Pioneira, 1989.

KAPPLER, A. Perfil da Alemanha. Frankfurt: Societäts-Verlag, 2013.

LEITÃO, M. Os 500 anos da Reforma Protestante, que abalou o mundo. Jornal O Globo.Disponível em: http://blogs.oglobo.globo.com/miriam-leitao/post/os-500-anos-dareforma-protestante-que-abalou-o-mundo.html. Acesso em 02.05.2017.

LINDBERG, C. História da Reforma. São Leopoldo: Sinodal, 2017.

MARTINA, G. História da Igreja: de Lutero aos nossos dias. v. 1: A era da Reforma. São Paulo: Loyola, 1997.

RUEB, F. 48 Variações sobre Bach. São Paulo: Companhia das Letras, 2001.

SCALZO, M. Jornalismo de Revista. São Paulo: Contexto, 2005. 